\title{
Post-infantile giant cell hepatitis: Histological and immunohistochemical study
}

\author{
S J Johnson, J Mathew, R N M MacSween, M K Bennett, A D Burt
}

\begin{abstract}
Aim-To determine the composition of the inflammatory infiltrate and to check for the presence of cytomegalovirus (CMV) and Epstein-Barr virus (EBV) in nine cases of post-infantile giant cell hepatitis.
\end{abstract}

Methods-The clinical, serological, and histological features of the nine cases were reviewed. Immunohistochemistry was used on liver biopsy specimens from six cases to: (i) characterise the lymphocytic infiltrate; (ii) assess the monocyte/macrophage response; (iii) detect "activated" perisinusoidal cells; and (iv) detect CMV and EBV antigens. Electron microscopic examination was carried out in two cases.

Results-Four patients had serological features suggestive of autoimmune chronic active hepatitis; in the other five cases the aetiology was obscure. Two patients presented with neurological symptoms. Hepatitis resolved completely in one patient; two patients showed clinical improvement; and one remained stable. Cirrhosis developed in three patients, one of whom proceeded to liver transplantation, and three patients died. Portal inflammation was present in all cases and lymphocytic piecemeal necrosis in eight cases, but intra-acinar inflammation associated with hepatocyte necrosis was observed in only five cases. The inflammatory infiltrate was composed predominantly of $T$ lymphocytes; an increase in monocyte/macrophage cells was also observed. Mallory bodies, often with associated neutophilic infiltrate, were present in four cases, and bilirubinostasis was a feature in four cases. "Activated" perisinusoidal cells were present, especially in relation to areas of inflammation, necrosis, and fibrosis. There was severe fibrosis or cirrhosis in five cases. Paramyxoviral nucleocapsids were not seen in the two cases examined ultrastructurally.

Conclusions-Post-infantile giant cell hepatitis should be viewed as a heterogeneous clinical and aetiological entity encompassing cases of hepatitis with extensive giant cell hepatocyte transformation.

(F Clin Pathol 1994;47:1022-1027)

Multinucleate hepatocytes are common in biopsy specimens from some neonatal and infantile liver diseases ${ }^{1}$ but are only occasionally found in adults. In adults hepatitis with extensive giant cell change ${ }^{2-8}$ has been labelled as either "post-infantile giant cell hepatitis" $(\mathrm{PIGCH})^{257}$ or "syncytial giant cell hepatitis". ${ }^{6}$ Some investigators have suggested that this pattern of hepatitis is a specific entity, possibly of paramyxoviral aetiology, ${ }^{6}$ which has a particularly poor prognosis. ${ }^{2}$ However, autoimmune disease, ${ }^{4-9}$ drugs ${ }^{10-13}$ and a variety of other viral infections ${ }^{79}$ have also been implicated as causes of giant cell hepatitis.

\section{Methods}

Biopsy material was available from nine patients (table 1). Two patients presented initially with neurological symptoms; abnormal liver function tests were subsequently found on routine investigation. There was no known history of transfusion or intravenous drug misuse in any patient. All patients denied alcohol misuse.

Liver function tests at presentation were abnormal in all cases with raised bilirubin, serum transaminases, and alkaline phosphatase activities. A blood smear from case 6 showed atypical mononuclear cells and two patients had slight eosinophilia. Serum autoantibodies were detected in cases $3,4,6$, 7,8 , and 9 , and immunoglobulin concentrations were raised in cases $3,4,5$, and 9.

Where results of serological investigations were available there was no evidence of recent infection with hepatitis A, B, or C, cytomegalovirus (CMV), Epstein-Barr virus (EBV), syphilis, or toxoplasmosis. In cases 5, 6 , and 9 serology for paramyxoviral infection was negative. Case 5 showed transient rises in titres of IgM and IgG to both CMV and EBV which were considered to be part of a polyclonal anamnestic response rather than evidence of recent specific infection; urine culture for CMV and the Paul Bunnell test were negative. Two patients showed serological evidence of recent influenza $B$ (case 4) and Mycoplasma pneumoniae (case 9) infections, but there was no temporal relation with the onset of hepatitis in either case.

Follow up information was available in all cases and repeat histology was available in four of these (cases 2, 5, 6, and 7). Cases 1, 2, and 3 died in hepatic failure with evidence of portal hypertension; of this group, case 2 had shown a transient clinical improvement with steroids a few months before death. Case 7 showed no substantial clinical or biochemical response to either a combination of prednisolone and azathioprine, or interferon. She 
Table 1 Clinical details of the nine patients with post-infantile giant cell hepatitis

\begin{tabular}{|c|c|c|c|c|c|c|c|c|c|c|}
\hline \multirow{2}{*}{$\begin{array}{l}\text { Case } \\
\text { No }\end{array}$} & \multirow{2}{*}{$\begin{array}{l}\text { Sex/ } \\
\text { age }\end{array}$} & \multirow{2}{*}{$\begin{array}{l}\text { Clinical } \\
\text { presentation }\end{array}$} & \multirow{2}{*}{$\begin{array}{l}\text { Previous medical } \\
\text { history }\end{array}$} & \multirow[b]{2}{*}{ Drugs } & \multicolumn{3}{|c|}{ Initial liver function tests } & \multirow{2}{*}{$\begin{array}{l}\text { Positive } \\
\text { auto- } \\
\text { antibodies }\end{array}$} & \multirow{2}{*}{$\begin{array}{l}\text { Positive } \\
\text { serology }\end{array}$} & \multirow[b]{2}{*}{ Outcome } \\
\hline & & & & & $B$ & $A L T$ & $A L P$ & & & \\
\hline $1^{\star}$ & F69 & $\begin{array}{l}\text { Jaundice, abdominal } \\
\text { pain }\end{array}$ & Nil of note & NK & $\uparrow$ & $\uparrow$ & $\uparrow$ & NK & NK & $\begin{array}{l}\text { Died. } \\
\text { Hashimoto's } \\
\text { thyroiditis } \\
\text { found at post } \\
\text { mortem } \\
\text { examination }\end{array}$ \\
\hline $3^{\star}$ & F41 & $\begin{array}{l}\text { Jaundice, nausea and } \\
\text { vomiting, pale stools, } \\
\text { pruritus, for two weeks }\end{array}$ & Nil of note & None & 468 & $\uparrow$ & $\uparrow$ & ASMA & None & Died \\
\hline $4^{\star}$ & $\mathrm{M} 12$ & $\begin{array}{l}\text { Jaundice, nausea and } \\
\text { vomiting, for four days }\end{array}$ & $\begin{array}{l}\text { Asthma. Recent } \\
\text { viral infection }\end{array}$ & None & 109 & 219 & NK & ANF & Influenza B & $\begin{array}{l}\text { Clinical } \\
\text { improvement }\end{array}$ \\
\hline 6 & F63 & $\begin{array}{l}\text { Progressive inability to } \\
\text { walk and tingling of } \\
\text { upper limbs, for one } \\
\text { week; abnormal liver } \\
\text { function tests }\end{array}$ & Asthma & None & 12 & 155 & 1160 & $\begin{array}{l}\text { Thyroid } \\
\text { micro- } \\
\text { somal } \\
\text { antibody }\end{array}$ & None & $\begin{array}{l}\text { Clinical } \\
\text { improvement }\end{array}$ \\
\hline 7 & F34 & $\begin{array}{l}\text { Tiredness, joint pains, } \\
\text { dark urine }\end{array}$ & $\begin{array}{l}\text { 1980-mild } \\
\text { rheumatoid } \\
\text { arthritis. } \\
\text { Recent travel } \\
\text { to Majorca }\end{array}$ & $\begin{array}{l}\text { Norethisterone } \\
\text { mefenamic } \\
\text { acid }\end{array}$ & 94 & $\begin{array}{l}\text { AST } \\
865\end{array}$ & 363 & None & None & $\begin{array}{l}\text { Developed } \\
\text { cirrhosis, } \\
\text { transplanted }\end{array}$ \\
\hline 8 & F76 & $\begin{array}{l}\text { General malaise for a few } \\
\text { months; abnormal liver } \\
\text { function tests }\end{array}$ & Depression & Clomipramine & 30 & 441 & 2500 & $\begin{array}{l}\text { Initially } \\
\text { anti- } \\
\text { thyroid } \\
\text { cytoplasmic } \\
\text { antibody } \\
\text { only. } \\
\text { Later: } \\
\text { ANF and } \\
\text { ASMA }\end{array}$ & None & $\begin{array}{l}\text { Clinical } \\
\text { improvement }\end{array}$ \\
\hline 9 & M40 & $\begin{array}{l}\text { Peripheral neuropathy, } \\
\text { tiredness for a few } \\
\text { months; abnormal liver } \\
\text { function tests }\end{array}$ & $\begin{array}{l}\text { Asthma. Recent } \\
\text { travel to } \\
\text { Europe and } \\
\text { USA }\end{array}$ & $\begin{array}{l}\text { Salbutamol } \\
\text { beclo- } \\
\text { methasone }\end{array}$ & 11 & 488 & 296 & ANF & $\begin{array}{l}\text { Mycoplasma } \\
\text { pneumoniae }\end{array}$ & $\begin{array}{l}\text { Clinical } \\
\text { improvement }\end{array}$ \\
\hline
\end{tabular}

* Detailed clinical information is not available for cases $1-4$.

$\mathrm{NK}=$ not known; $\mathrm{B}=$ total bilirubin $(\mu \mathrm{mol} / \mathrm{l}) ; \mathrm{ALT}=$ alanine amino transferase $(\mathrm{IU} / \mathrm{l}) ; \mathrm{AST}=$ asparate transaminase $(\mu \mathrm{mol} / \mathrm{l}) ; \mathrm{ALP}=$ alkaline phosphatase $(\mathrm{IU} / \mathrm{l})$; ASMA = anti-smooth muscle antibody; ANF = antinuclear factor; $\mathrm{HAV}=$ heptaitis $\mathrm{A}$ virus; CMV = cytomegalovirus; EBV = Epstein-Barr virus.

developed cirrhosis with oesophageal varices and hypersplenism necessitating splenectomy, and underwent orthotopic liver transplantation in 1991; to date, there has been no recurrence of giant cell hepatitis in the donor liver. Case 6 showed initial clinical improvement but a repeat biopsy specimen showed increased hepatic fibrosis. Case 4 is clinically stable and has responded to steroids. Cases 8 and 9 were also showing clinical improvement at the time of writing. Complete clinical recovery occurred in case 5 and was associated with histological resolution.

On each liver biopsy or necropsy specimen, the following histochemical stains were performed: haematoxylin and eosin, periodic acid

Table 2 Antibodies used for immunohistochemistry

\begin{tabular}{llll}
\hline Antibody & Source & Clone & Dilution \\
\hline Anti-CMV antigen & Dako UK & CCH2 & $1 / 50$ \\
Anti-EBV antigen & Dako UK & CS1-4 & $1 / 50$ \\
Anti-ubiquitin & Dako UK & polyclonal & $1 / 1000$ \\
Antibody to B lymphocytes & Dako UK & L26 (1,2,3) & $1 / 400$ \\
Antibody to T lymphocytes & Dako UK & UCHL1 & $1 / 400$ \\
Anti-macrophages/monocytes Dako UK & KP1 & $1 / 50$ \\
Anti- $\alpha$-smooth muscle actin & Sigma UK & IA4 & $1 / 500$ \\
\cline { 3 - 4 } & & &
\end{tabular}

Schiff (PAS), diastase-PAS, picro-Mallory, van Gieson, Shikata's orcein, Perls's Prussian blue stain, and Gordon and Sweets's reticulin.

Material was available for immunohistochemistry from cases $1,4,6,8,9$, the first biopsy specimen from case 5 , and the second biopsy specimen from case 7. An indirect immunoperoxidase procedure was performed using the antibodies shown in table 2 . Sections treated with normal rabbit or mouse serum in place of primary antibody were used as negative controls; 3,3'-diaminobenzidine was used as chromogen. Mallory bodies were identified both on haematoxylin and eosin staining and labelling with anti-ubiquitin antibody. ${ }^{14}$

Features of chronic hepatitis were scored according to the method described by Scheuer ${ }^{15}$ as follows: portal/periportal inflammation: $0=$ none or minimal; $1=$ portal inflammation; $2=$ mild piecemeal necrosis; 3 = moderate piecemeal necrosis; $4=$ severe piecemeal necrosis. Acinar inflammation: $0=$ none; $1=$ inflammation but no necrosis; $2=$ focal necrosis or acidophil bodies; $3=$ severe focal cell damage; $4=$ bridging necrosis. Fibrosis/cirrhosis: $0=$ none; $1=$ 
Table 3 Histological characteristics of nine cases of PIGCH

\begin{tabular}{|c|c|c|c|c|c|c|c|c|c|}
\hline \multirow[b]{2}{*}{$\begin{array}{l}\text { Case } \\
\text { No }\end{array}$} & \multirow[b]{2}{*}{ Biopsy } & \multirow[b]{2}{*}{$\stackrel{\text { (a) }}{\text { Giant cells }}$} & \multirow{2}{*}{$\begin{array}{l}\text { (b) } \\
\text { Mallory } \\
\text { bodies }\end{array}$} & \multirow[b]{2}{*}{$\begin{array}{l}\text { (b) } \\
\text { Neutrophils }\end{array}$} & \multirow{2}{*}{$\begin{array}{l}\text { (b) } \\
\text { Bilirubin- } \\
\text { ostasis }\end{array}$} & \multirow{2}{*}{$\begin{array}{l}\text { (b) } \\
\text { Ductular } \\
\text { proliferation }\end{array}$} & \multicolumn{3}{|c|}{ Scheuer scoring for features of chronic hepatitis } \\
\hline & & & & & & & $\begin{array}{l}\text { Portal/periportal } \\
\text { inflammation }\end{array}$ & $\begin{array}{l}\text { Acinar } \\
\text { inflammation }\end{array}$ & $\begin{array}{l}\text { Fibrosis } \\
\text { cirrhosis }\end{array}$ \\
\hline 1 & \multirow{5}{*}{$\begin{array}{l}\text { first } \\
\text { second }\end{array}$} & +++ & - & $\mathbf{P +}$ & $\mathrm{C}, \mathrm{H}+$ & ++ & 2 & 3 & 3 \\
\hline 2 & & ++ & - & $\mathrm{P}, \mathrm{A}+$ & $\mathrm{C}, \mathrm{H}++$ & - & 3 & 3 & 3 \\
\hline & & ++ & ++ & $\mathrm{P}, \mathrm{A}+$ & $\mathrm{C}, \mathrm{H}++$ & - & 3 & 3 & 4 \\
\hline 3 & & ++ & - & $\mathrm{P}+$ & $\mathrm{C}++$ & ++ & 3 & 4 & 1 \\
\hline 4 & & +++ & - & $\mathrm{P}+$ & - & + & 3 & 3 & 4 \\
\hline \multirow[t]{3}{*}{5} & \multirow{3}{*}{$\begin{array}{l}\text { first } \\
\text { second } \\
\text { third }\end{array}$} & +++ & - & - & $C+$ & - & 0 & 3 & 1 \\
\hline & & ++ & - & $\mathbf{P}+$ & - & - & 2 & 1 & 2 \\
\hline & & + & - & - & - & - & 0 & 0 & 1 \\
\hline \multirow[t]{2}{*}{6} & \multirow{6}{*}{$\begin{array}{l}\text { first } \\
\text { second } \\
\text { first } \\
\text { second }\end{array}$} & ++ & + & $\mathbf{P}, \mathbf{A}+$ & - & ++ & 2 & 1 & 2 \\
\hline & & ++ & - & - & - & + & 2 & $\mathrm{i}$ & 3 \\
\hline 7 & & +++ & - & $\mathbf{P}, \mathbf{A}+$ & $\mathrm{C}+$ & - & 2 & 3 & 3 \\
\hline & & ++ & ++ & $\mathbf{P}, \mathrm{A}+$ & - & + & 3 & 3 & 4 \\
\hline 8 & & ++ & + & $\mathbf{P}, \mathbf{A}++$ & - & - & 2 & 2 & 2 \\
\hline 9 & & ++ & + & - & - & - & 1 & 2 & 0 \\
\hline
\end{tabular}

(a) $+<1 / 3$ of parenchymal area; $++1 / 3-2 / 3$ of parenchymal area; $+++>2 / 3$ of parenchymal area; (b) + infrequent; ++ frequent; - absent; $\mathrm{P}=$ portal; $\mathrm{A}=$ acinar; $\mathrm{C}=$ canalicular; $\mathrm{H}=$ cytoplasmic (hepatocellular).

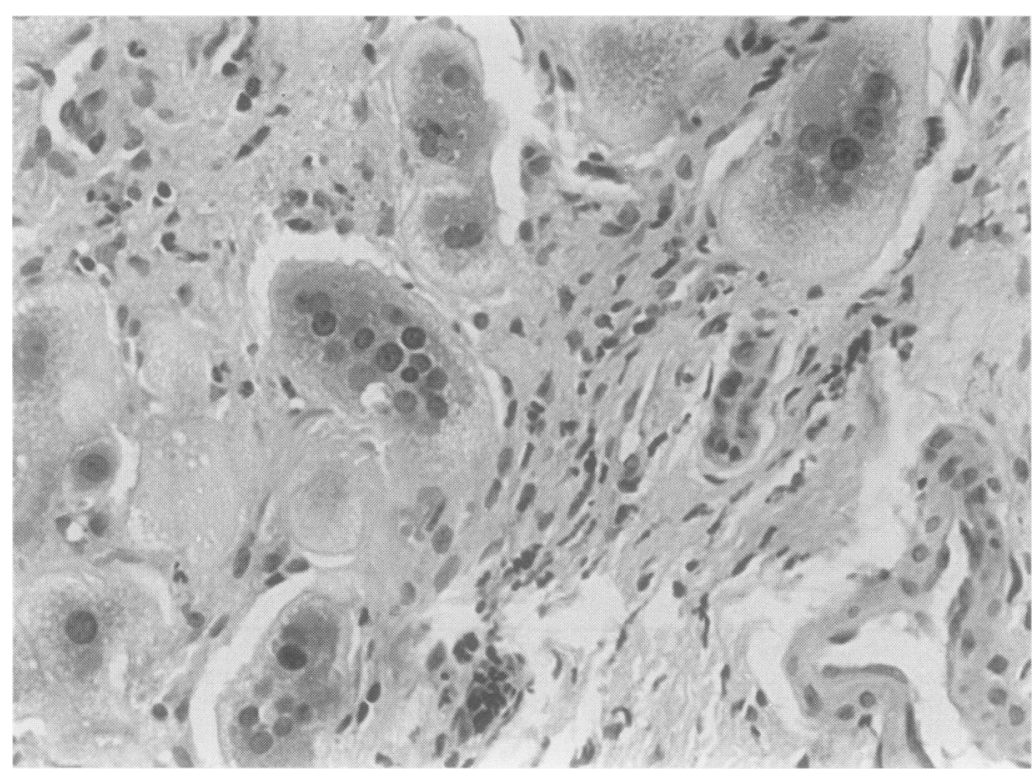

Figure 1 Giant cell transformation of hepatocytes: note multinucleation of many hepatocytes in this field (case 7) (haematoxylin and eosin).

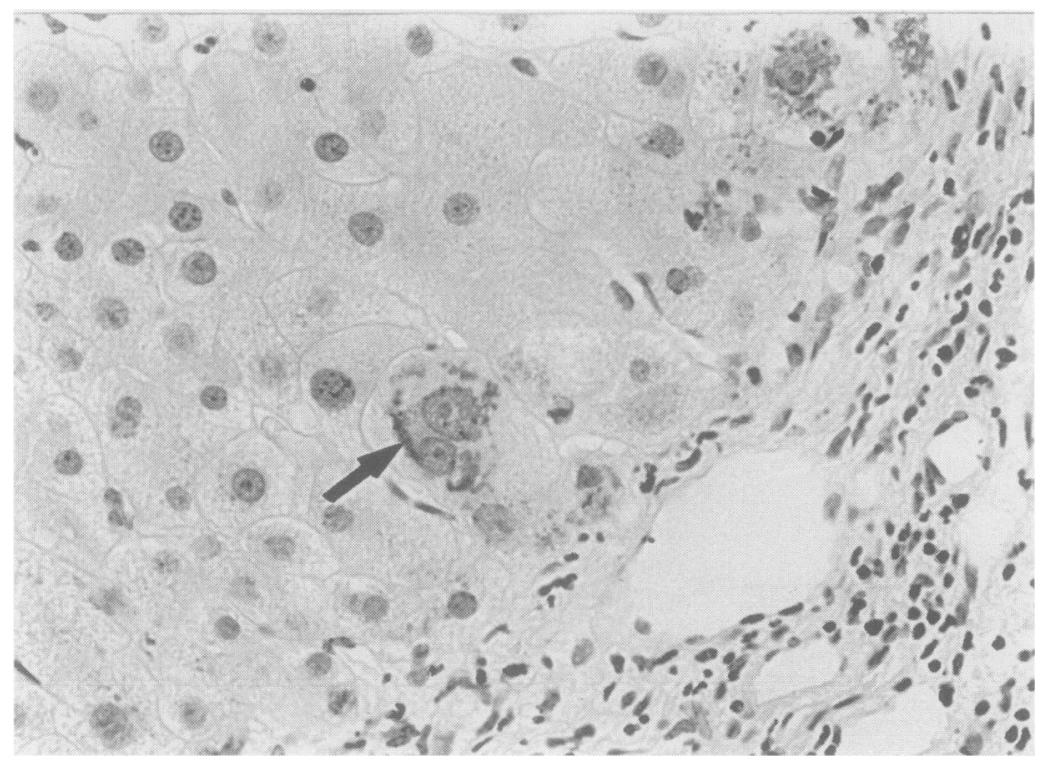

Figure 2 Mallory bodies (arrow) in a binucleate periportal hepatocyte (case 7) (haematoxylin and eosin). enlarged fibrotic portal tracts; 2 = periportal or portal-portal septa; $3=$ fibrosis with architectural distortion; $4=$ cirrhosis.

\section{Results}

The histological findings in our nine cases are summarised in table 3 . All cases showed extensive giant cell transformation of hepatocytes; in most cases the giant cell change affected more than two thirds of the parenchyma (fig 1). Giant cell transformation was most pronounced in periportal and periseptal zones, although in four cases this change was pan-acinar. The giant cells seemed to be limited to liver cell plates and occasionally contained up to 15 centrally located nuclei. Rare single mitotic figures could be found within multinucleate cells. In many cases degenerative cytoplasmic changes were seen involving hepatocytes and giant cells, particularly in periportal areas. Mallory bodies, often within giant cells, were prominent in haematoxylin and eosin stained sections of cases 2 and 7 (fig 2), but could also occasionally be found in ubiquitin labelled sections of cases 6,8 , and 9. Canalicular and cytoplasmic bilirubinostasis, also involving giant cells, was present in four cases (fig 3); some of these showed mild ductular proliferation, although the bile ducts were normal in all cases. Steatosis was not a major feature in any of the biopsy specimens.

An inflammatory infiltrate made up predominantly of mature lymphocytes was present within portal tracts in all cases. Immunohistochemistry showed that this infiltrate was composed almost exclusively of UCHL1 positive T lymphocytes. Occasional neutrophils, eosinophils, and L26 positive B lymphocytes were also seen in portal tracts. In eight cases mild to moderate lymphocytic piecemeal necrosis was observed. Five cases showed a prominent intra-acinar lymphocytic inflammatory infiltrate associated with focal or bridging hepatocyte necrosis. In two cases numerous neutrophils were observed within the acinus; these were often seen around giant cells containing Mallory bodies (fig 4). 


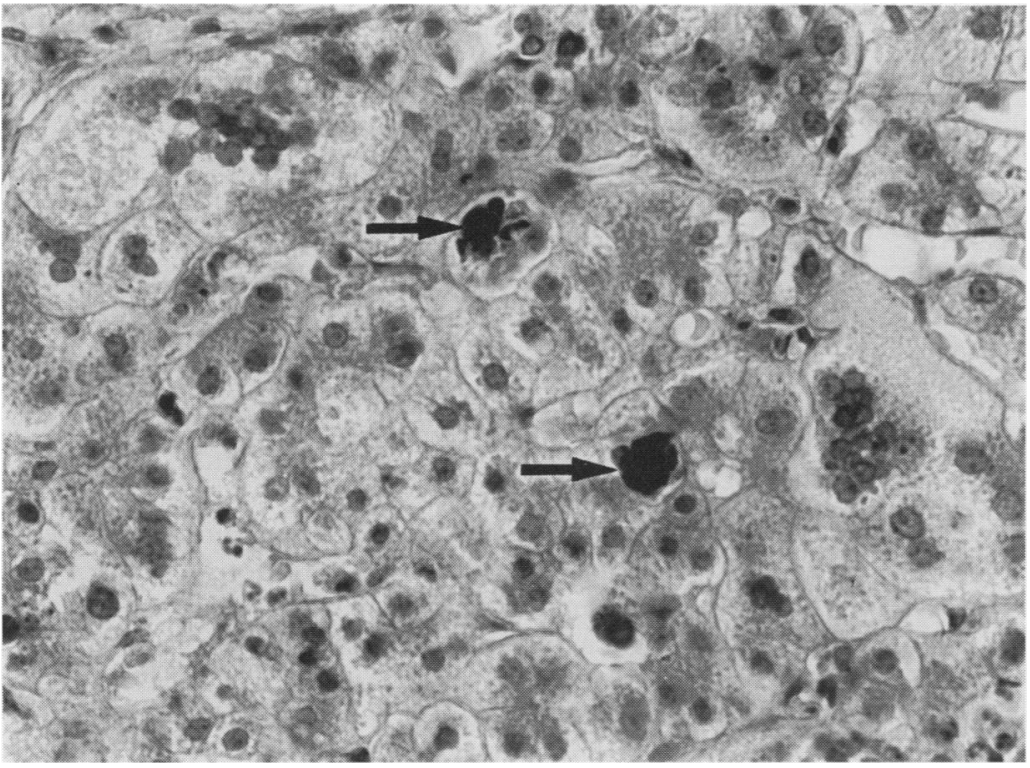

Figure 3 Canalicular bilirubinostasis in a field which also contains multinucleate hepatocytes (arrows = bile plugs) (case 2) (haematoxylin and eosin).

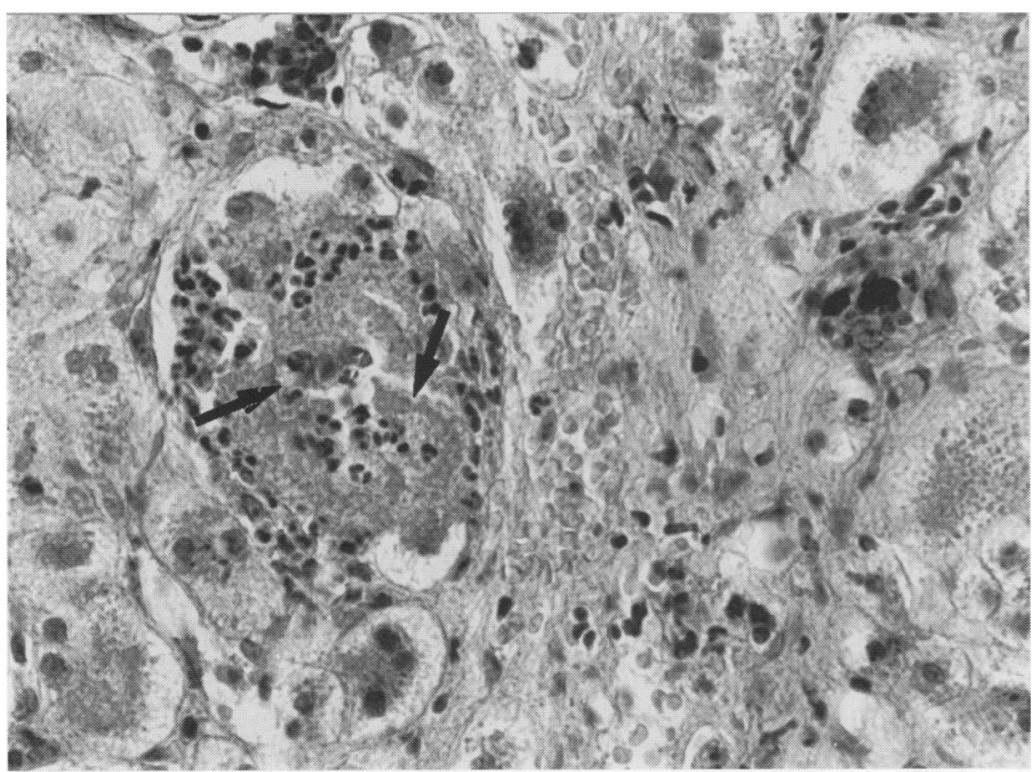

Figure 4 Neutrophils surrounding Mallory bodies (arrows) within a multinucleate hepatocyte (case 2) (haematoxylin and eosin).

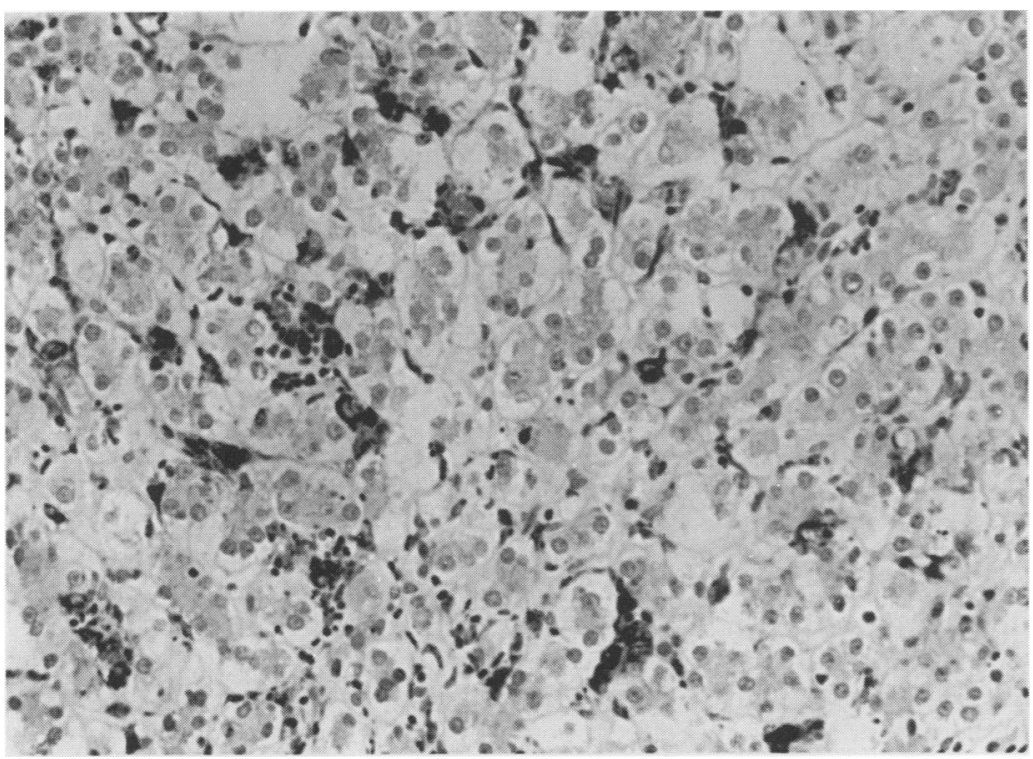

Figure 5 Immunohistochemical labelling with the antibody KP1 showing increased
Increased numbers of KP1 positive monocytes/macrophages were seen in four cases, particularly in areas of parenchymal necrosis; this increase was most striking in case 1 and the first biopsy specimen from case 5 (fig 5 ).

Sections labelled with anti- $a$-smooth muscle actin ( $a$-SMA) antibody showed an increase in "activated" perisinusoidal cell numbers; these cells were found predominantly in areas of intra-acinar inflammation and around foci of piecemeal necrosis and ductular proliferation (fig 6). All cases showed some degree of periportal fibrosis; severe fibrosis was present in cases $1,2,6$, and 7 , and cirrhosis in case 4 ; progression to cirrhosis was evident in the second biopsy specimens from cases 2 and 7 . Perivenular and periportal pericellular fibrosis was present in the initial biopsy specimens from cases 5 and 7 . In case 5 follow up biopsy specimens showed resolution of the inflammatory infiltrate and hepatocyte giant cell change, although there was minimal residual periportal fibrosis.

Immunohistochemistry for CMV and EBV antigens was negative in all cases. No viral nucleocapsids were identified in the two cases examined ultrastructurally.

\section{Discussion}

The patients described in this study formed a heterogeneous group with respect to their clinical and histological findings, but had in common an unusual histological pattern of hepatitis in which there was extensive giant cell change of hepatocytes that involved at least one third of the parenchymal area.

Giant hepatocytes are characteristically found in several neonatal and infantile liver diseases such as extrahepatic biliary atresia, paucity of intrahepatic bile ducts, some chromosomal and metabolic disorders, and various viral infections. ${ }^{1617}$ By contrast, giant cells are rarely found in adult liver disease. In adults multinucleate hepatocytes have been seen after treatment with drugs such as methotrexate, ${ }^{10} 13$ clometacin, ${ }^{11}$ and 6-mercaptopurine, ${ }^{12}$ and occasional giant cells may be found in some cases of autoimmune chronic active hepatitis and hepatitis C. ${ }^{18}$ The combination of hepatitis and extensive giant cell change in adult liver has been referred to as "post-infantile giant cell hepatitis" 257 or "syncytial giant cell hepatitis". 6

Giant cell transformation is a characteristic cytopathic effect of many viruses, especially the paramyxoviruses, ${ }^{19}$ and this has led several authors to suggest that PIGCH may be an infective, possibly viral, condition. Phillips et $a l^{6}$ described a series of patients with "syncytial giant cell hepatitis" in whom ultrastructural examination of the liver biopsy specimens showed cytoplasmic particles resembling paramyxovirus nucleocapsids. Injection of liver homogenate from the index case into two chimpanzees produced a raised paramyxoviral antibody titre without hepatitis in one chimpanzee but no response in the second. These authors therefore suggested that a paramyxoviral infection should be considered in all cases of syncytial giant cell hepatitis. 


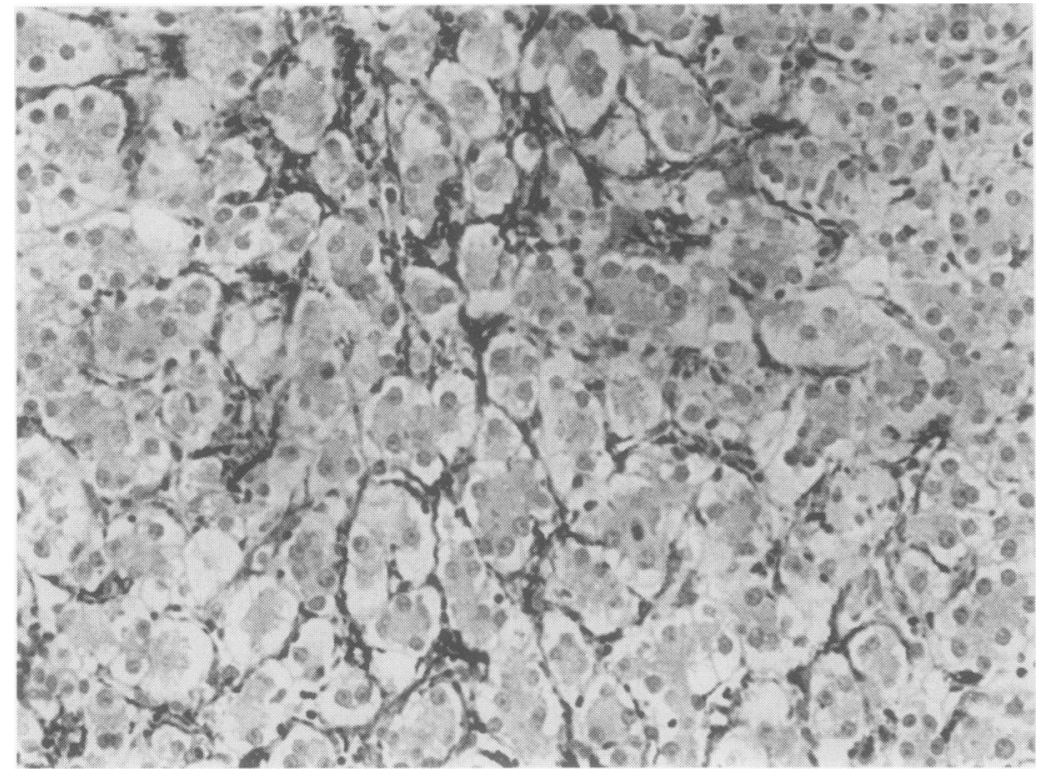

Figure 6 Immunohistochemical labelling with anti-a-SMA antibody showing numerous "activated" perisinusoidal cells in association with intra-acinar inflammation (first biopsy specimen, case 5). muscle antibody or antinuclear factor. In three cases $(3,4$, and 9) this was associated with hypergammaglobulinaemia (immunoglobulin concentrations in case 8 were not known). Histological features of chronic active hepatitis, including portal inflammation with piecemeal necrosis and portal fibrosis, were seen in liver biopsy specimens from these cases. Interestingly, thyroid autoantibodies were positive in cases 6 and 8 , and Hashimoto's thyroiditis was noted in case 1 at post mortem examination. Steroid responsiveness was noted in cases 4,5 , and 8 , and transiently in case 2 .

Portal lymphocytic infiltration was present in all our cases. In addition, lymphocytic piecemeal necrosis was observed in eight cases and a prominent intra-acinar lymphocytic inflammatory infiltrate in five cases. These lymphocytes were mostly $T$ cell in origin. In four cases increased numbers of KP1 positive monocytes/macrophages were also seen, especially in areas of parenchymal necrosis. An increase in the number of $a$-SMA positive "activated" perisinusoidal cells was also noted, especially in areas of inflammation, necrosis, and fibrosis. Similar alterations in monocyte/macrophage and perisinusoidal cells have been described in other types of chronic liver injury in man, ${ }^{23-25}$ and our findings are also entirely consistent with the proposed role of these cells in the response to liver injury and the development of hepatic fibrosis.

Mallory bodies were present in four cases, frequently within the giant cells. The presence of numerous Mallory bodies in case 2 was probably related to prolonged cholestasis; the cholestasis was confirmed by the finding of copper associated protein in periportal areas using the orcein stain. Neutrophils were a prominent component of the inflammatory infiltrate in five of our cases; this feature can be explained by the fact that Mallory bodies are chemotactic for neutrophils. Mallory bodies with associated neutrophils are characteristically seen in alcoholic hepatitis and non-alcoholic steatohepatitis (NASH); in our cases clinically relevant steatosis was absent and there was no history of alcohol misuse or any risk factor for NASH.

The reason for the development of multinucleated hepatocytes in PIGCH is unclear but these cells may result either from nuclear division without cytoplasmic division or from union of mononuclear hepatocytes. There is ultrastructural evidence supporting both nuclear division ${ }^{326}$ and cell fusion, ${ }^{9}$ and both mechanisms may in fact be involved, either alone or in combination. In infants multinucleation of hepatocytes is considered to be a relatively non-specific response of ontologically less mature hepatocytes to a variety of insults, especially viral infections. ${ }^{17}$ In adults giant cell change of hepatocytes probably represents an unusual and idiosyncratic regenerative response to a wide variety of hepatic stimuli, although in some cases a cytopathic effect, possibly virally induced, may also be a factor. eatures of autoimmunity have described in some cases of PIGCH. ${ }^{7-9}$ In our series there was evidence consistent with autoimmune chronic active hepatitis in cases $3,4,8$, and 9. These patients had anti-smooth 
In our opinion the term "post-infantile giant cell hepatitis" should be used for cases of acute and chronic hepatitis in adults with extensive hepatocyte multinucleation. These cases are heterogeneous in terms of their clinical, serological, and histological features. A histological diagnosis is therefore descriptive and does not establish the aetiology in an individual case.

We thank the following for permission to include their patients in this series: Dr R Holden, Monklands Hospital, Lanarkshire Professor DG Young and Dr KM Goel, Royal Hospital for Sick Children, University of Glasgow; Dr JG Freeman and D CS Holgate, Derbyshire City Hospital and Derbyshire Roya Infirmary, Derby; Dr Somasundram and Dr D Henderson, Friarage Hospital, Northallerton; Dr D Hemming, Hexham General Hospital, Hexham, Northumberland; Professor OFW James and Dr MF Bassendine, Freeman Hospital, Newcastle upon Tyne; Dr CO Record, Royal Victoria Infirmary, Newcastle upon Tyne; and Dr P Hudgson, Newcastle General Hospital, Newcastle upon Tyne.

We also thank Mrs $\mathrm{K}$ Reach for assistance with the immunohistochemistry, Mrs E Tweedy for secretarial assistance, and $\mathrm{Mr}$ S Brabazon for the photography.

1 Montgomery CK, Ruebner BH. Neonatal hepatocellular giant cell transformation: a review. Perspect Pediatr Pathol 976;3:85-101.

2 Thaler H. Post-infantile giant cell hepatitis. Liver 1982;2 393-403.

3 Richey J, Rogers S, Van Thiel DH, Lester R. Giant multinucleated hepatocytes in an adult with chronic active hepatitis. Gastroenterology 1977;73:570-4.

4 Thijs JC, Bosma A, Henzen-Logmans SC, Meuwissen SGM. Postinfantile giant cell hepatitis in a patient with multiple autoimmune features. Am $\mathcal{f}$ Gastroenterol 1985; 80:294-7.

5 Kumar A, Minuk GY. Postinfantile giant cell hepatitis in association with hypereosinophilia. Gastroenterology 1991;101:1417-19.

6 Phillips MJ, Blendis LM, Poucell S, Patterson J, Petric M, Roberts E, et al. Syncytial giant-cell hepatitis: sporadic hepatitis with distinctive pathological features, a sever clinical course, and paramyxoviral features. $N$ Eng $\mathcal{F} M e d$ 1991;324:455-60.

7 Lau JYN, Koukoulis G, Mieli-Vergani G, Portmann BC, Williams R. Syncytial giant-cell hepatitis-a specific disease entity? f Hepatol 1992;15:216-9.

8 Devaney K, Goodman ZD, Ishak KG. Postinfantile giantcell transformation in hepatitis. Hepatology 1992;16:
327-33.

9 Dienes HP, Protzer U, Gerken G, Bianchi L, Schirmacher $P$, Klinge $O$. Pathogenesis and clinical relevance of postinfantile giant cell hepatitis (PIGCH). Hepatology 1993; infantile

10 Dubin HV, Harrell ER. Liver disease associated with methotrexate treatment of psoriatic patients. Arch Dermatol 1970;102:498-503.

11 Pessayre D, Degos F, Feldmann G, Degott C, Bernuau J, Benhamou J-P. Chronic active hepatitis and giant multinucleated hepatocytes in adults treated with clometacin. Digestion 1981;22:66-72.

12 McIlvanie SK, MacCarthy JD. Hepatitis in association with prolonged 6-mercaptopurine therapy. Blood 1959; 14:80-90.

13 Coe RO, Bull FE. Cirrhosis associated with methotrexate treatment of psoriasis. $\mathcal{F} A M A 1968 ; 206: 1515-20$

14 Tiniakos DG, Harrison D, Burt AD. Detection of Mallory bodies in human liver biopsies by immunolocalisation of ubiquitin: comparison with other histochemical and immunohistochemical methods. Hepatology 1992;16: imm.

15 Scheuer PJ. Classification of chronic viral hepatitis: a need for reassessment. $\mathcal{F}$ Hepatol 1991;13:372-4.

16 Witzleben CL, Marshall GS, Wenner W, Piccoli DA, Barbour SD. HIV as a cause of giant cell hepatitis. Hum Pathol 1988;19:603-5.

17 Aterman K. Neonatal hepatitis and its relation to viral hepatitis of mother-a review of the problem. Am $\mathcal{F}$ Dis Child 1963;105:395-416.

18 Bach N, Thung SN, Schnaffner F. The histological features of chronic hepatitis $\mathrm{C}$ and autoimmune chronic hepatitis: a comparative analysis. Hepatology 1992;15: h72-7.

19 Enders JF, McCarthy K, Mitus A, Cheatham WJ. Isolation of measles virus at autopsy in cases of giant-cell pneumonia without rash. $N$ Engl $f$ Med 1959;261: 875-81.

20 Anonymous. Hepatitis G? [Editorial.] Lancet 1991;337: 1070

21 Koff RS. Acute and chronic giant cell hepatitis: a paramyxovirus infection? Gastroenterology 1991;101:863-4.

22 Yunis E, Agostini R. Syncytial giant cell hepatitis. N Engl f Med 1992;327:130-1.

23 Mathew J, Burt AD. Cellular mechanisms of fibrogenesis in genetic haemochromatosis. In: Knook DL, Wisse E, in genetic haemochromatosis. In: Knook DL, Wisse E, eds. Cells of the hepatic sinusoid. Vol. 4. Rijswikg

24 Mathew J, Hines J, Toole K, Johnson SJ, James OFW, Burt $\mathrm{AD}$. Quantitative analysis of macrophages and perisinusoidal cells in primary biliary cirrhosis. Histopathology 1994;25:65-70

25 Schmitt-Gräff A, Krüger S, Bochard F, Gabbiani G, Denk H. Modulation of alpha smooth muscle actin and desmin expression in perisinusoidal cells of normal and diseased human livers. Am 7 Pathol 1991;138:1233-42.

26 Elsner B. Ultrastructural studies in giant cell transformation of the liver. Medicina 1973;33:248-54. 